\title{
The Effect of the ICARE Learning Model in Distance Learning on the Mathematical Problem Solving Ability of SMK Negeri 2 Karawang Students
}

\author{
Al Wanita Imani Hikmatuprilla ${ }^{1 *}$, Lukita Ambarwati ${ }^{2}$, Dwi Antari Wijayanti ${ }^{3}$ \\ ${ }_{1,2,3}$ Universitas Negeri Jakarta \\ *dwi-antari@unj.ac.id
}

Received: May 2021. Accepted: June 2021. Published: July 2021.

\begin{abstract}
This study aims to obtain empirical information about the effect of implementing the ICARE learning model (Introduction, Connect, Apply, Reflect, Extend) in distance learning on students' problem-solving abilities at SMK Negeri 2 Karawang. The research method used was a quasi-experimental with posttest-only control group design. The population in this study were all class X students at SMK Negeri 2 Karawang. Sampling using Cluster Random Sampling and Simple Random Sampling. Class X TB 1 was chosen to be the experimental class and class X TB 3 was selected as the control class. The results of the statistical hypothesis testing was then carried out using the t'-test of two independent samples with a significant level of 5\% concluded that the mean test results of students' mathematical problem-solving abilities in the experimental class were higher than the control class, this shows that the ICARE learning model in distance learning has a significant effect on the mathematical problem-solving abilities of students at SMK Negeri 2 Karawang on the sequence and series material. The large effect test carried out obtained the result of $\boldsymbol{d}=0.8$, the influence given is $79 \%$ and is included in the large category.

Keywords: learning model ICARE (Introduction, Connect, Apply, Reflect, Extend), distance learning, mathematical problem solving ability.
\end{abstract}

How to Cite: Hikmatuprilla, A. W. I., Ambarwati, L., \& Wijayanti, D. A. (2021). The Effect of the ICARE Learning Model in Distance Learning on the Mathematical Problem Solving Ability of SMK Negeri 2 Karawang Students. Journal of Medives: Journal of Mathematics Education IKIP Veteran Semarang, 5(2), 317-328. 


\section{PENDAHULUAN}

Matematika dapat disebut sebagai mata pelajaran yang selalu ditemui oleh peserta didik di setiap tingkatan pendidikan. Peran matematika dalam pendidikan sangat penting juga dimanfaatkan untuk mengembangkan cara bernalar peserta didik, tak hanya di kelas, cara bernalar tersebut juga yang nantinya dapat diaplikasikan dalam kehidupan. Menurut Utami dan Wutsqa pada penelitiannya mengatakan matematika diajarkan di sekolah dan mampu memperbaiki permasalahan yang ada pada realita sehari-hari (Utami \& Wutsqa, 2017).

Proses belajar matematika di kelas menjadi suatu unsur yang penting dalam proses pendidikan peserta didik di semua jenjang tetapi, karena saat ini sedang mewabahnya Coronavirus Disease (Covid-19) yang berdampak signifikan pada proses pendidikan. Pandemi Covid19 ini telah membawa banyak perubahan kebijakan untuk diterapkan. Kebijakan baru yang diterapkan pada bidang pendidikan tersebut mengubah pembelajaran yang sebelumnya peserta didik dan guru harus datang ke kelas menjadi belajar di rumah (Nurani et al., 2020).

Salah satu solusi yang dilakukan oleh hampir setiap sekolah pada semua jenjang pendidikan agar pembelajaran tetap berlangsung yaitu, sekolah menerapkan sistem pembelajaran jarak jauh atau bisa disebut juga sebagai pendidikan jarak jauh. Pembelajaran ini digunakan alat elektronik seperti smatrphone atau laptop sebagai media penghubung dan juga, pembelajaran seperti yang sudah disebutkan biasa disebut juga sebagai e-learning atau electronic learning (Hanifah et al., 2019).

Pada pembelajaran jarak jauh, peserta didik sangat dianjurkan belajar secara mandiri dan bertanggung jawab pada proses belajarnya. Peserta didik sebaiknya dapat menyusun rancangan dan mencari materi dengan usaha dan inisiatifnya sendiri (Kusuma \& Hamidah, 2020).

Pemecahan masalah menjadi satu dari 5 keahlian yang direkomendasikan NCTM (NCTM, 2000). Peserta didik yang terlatih menyelesaikan dan menghadapi masalah pada kehidupan yang sebenarnya, dapat mengambil keputusan agar dapat menghadapi masalah, karena hal itu memungkinkan peserta didik untuk mendapatkan informasi yang sesuai, mencermati informasi, dan sadar tentang pentingnya menelaah lagi hasil yang sudah didapatkan.

Pada pengertian seelumnya dijelaskan kemampuan pemecahan masalah matematis termasuk hal yang sangat diperlukan bagi peserta didik dalam menyelesaikan persoalan-persoalan matematis di kelas, akan tetapi hal ini tidak sesuai dengan kemampuan sesungguhnya. Hal itu dapat terlihat dari survei Programme for International Student Assessment (PISA) yang menunjukan bahwa pelajar Indonesia ada di bawah rata-rata negara OECD. Poin yang didapat pada tes matematika hanya 379 dari rata-rata OECD yaitu 487 (OECD, 2019).

Selanjutnya, penilaian Kemendikbud menunjukan UN tahun 2019, nilai rata-rata UN matematika SMA pada jurusan IPA (Ilmu Pengetahuan Alam) adalah 39,33, untuk SMA jurusan IPS 
(Ilmu Pengetahuan Sosial) rata-ratanya 34,46, SMA jurusan Bahasa 37,53 dan pada SMK (semua jurusan) 35,26. Di antara materi yang diujikan tersebut terdapat soal-soal yang menuntut kemampuan pemecaan masalah matematis (Kemendikbud, 2019). Jika dilihat dari data tersebut, rerata nilai ujian peserta didik di SMK lebih rendah jika dibandingkan rerata nilai peserta didik tingkat SMA.

Keberhasilan peserta didik yang belum optimal terhadap capaian hasil belajar matematika karena terdapat kesulitan belajar pada peserta didik dan kurangnya motivasi untuk belajar matematika. Ada beberapa faktor yang memengaruhi peserta didik, salah satunya karena matematika dinilai sebagai mata pelajaran yang tidak mudah untuk dimengerti oleh peserta didik dan mereka cenderung tergantung pada penjelasan yang dipaparkan guru akibatnya mereka tidak bisa mengerjakan soal tentang memecahkan masalah matematis secara mandiri. Faktor selanjutnya yang diduga mengakibatkan peserta didik kesulitan untuk memecahkan masalah yaitu karena pembelajaran bertaut dengan guru pada pemberian materi dan penyelesaian soal sehingga peserta didik selalu bergantung pada penjelasan dari dari guru dan pelajaran hanya berpusat pada penggunaan rumus atau algoritma tertentu (Rosselyne et al., 2020).

Sistem yang berbeda dengan biasanya membuat peserta didik harus beradaptasi pada pembelajaran jarak jauh ini. Pada pembelajaran jarak jauh para peserta didik dibutuhkan untuk dapat mengkonstruksi pengetahuannya sendiri dengan tetap diberikan arahan oleh guru. Proses mengajar yang dipakai guru memberi peranan aktif dalam mengembangkan kemampuan peserta didik model pembelajaran yang bisa diaplikasikan pada proses belajar jarak jauh satu diantaranya yaitu ICARE (Inroduction, Connect, Apply, Reflect, Extend).

Dalam pembelajaran ICARE akan ada proses pemecahan masalah yang diharapkan dapat mengasah kemampuan pada penyelesaian soal berbasis masalah. Carni dan kawan kawan pada penelitiannya menytakan bahwa, dengan menggunakan ICARE, peserta didik mendapatkan arahan agar andal dalam membangun dan mengaitkan pengetahuannya agar mampu menemukan pengertian dari masalah yang diperoleh sehingga mampu mengerti konsep dalam masalah yang didapatkan (Carni et al., 2016).

Yumiati dan Wahyuningrum pada penelitiannya menilai bahwa pembelajaran ICARE merupakan pembelajaran yang mampu mengubah proses $e$ learning menjadi lebih efisien pada pengembangan keahlian peserta didik untuk memecahkan masalah (Yumiati \& Wahyuningrum, 2015). Hal tersebut ada pada tahap ke-dua, dimana tahapan connect yang merupakan tahap pembelajaran ICARE yang terdapat langkah yang mengaitkan pengetahuan baru pada persoalan yang berkenaan dengan realita sehari-hari dan pengetahuan sebelumnya. Sama halnya dengan tahapan ketiga yaitu apply diberikan persoalan yang berhubungan dengan realita dimana butuh kemampuan pemecahan masalah di setiap proses penyelesaiannya. Selanjutnya, tahapan 
keempat juga kelima yaitu reflect dan extend, dibutuhkan daya peserta didik untuk pemecahan masalah, karena tahapan tersebut memberi peserta didik kesempatan dalam menambah pengetahuan dengan berlatih soal.

Maryam dalam penelitiannya menyimpulkan bahwa penerapan strategi ICARE dapat meningkatkan kemampuan pemecahan masalah matematis, dengan adanya peningkatan kegiatan saat melakukan pembelajaran dan adanya perkembangan pada respon positif peserta didik (Maryam, 2016). Dari hasil penelitian tersebut kegiatan pembelajaran ICARE bisa menjadi salah satu solusi untuk mengembangkan kemampuan peserta didik dalam mengerjakan soal pemecahan masalah. Penelitian ini dilaksanakan dengan menggunakan materi Barisan dan deret.

Dari penjelasan di atas, peneliti telah melakukan penelitian dengan fokus sebagai berikut (1) Apakah terdapat pengaruh penerapan model pembelajaran ICARE (Inroduction, Connect, Apply, Reflect, Extend) pada pembelajaran jarak jauh terhadap kemampuan pemecahan masalah matematis peserta didik di SMK Negeri 2 Karawang? (2) Seberapa besar pengaruh yang diberikan oleh model pembelajaran ICARE pada pembelajaran jarak jauh terhadap kemampuan pemecahan masalah matematis peserta didik di SMK Negeri 2 Karawang? Adapun tujuan dari penelitian ini adalah untuk mengetahui perbandingan kemampuan pemecahan masalah matematis peserta didik yang belajar menggunakan model pembelajaran ICARE dengan pendekatan konvesional pada pembelajaran jarak jauh.

\section{METODE PENELITIAN}

Penelitian ini menggunakan pendekatan kuantitatif dengan metode eksperimen. Bentuk eksperimen yang digunakan dalam penelitian ini adalah quasi experiment. Desain penelitian yang digunakan ialah posttest-only control group design. Populasi dalam penelitian ini adalah seluruh peserta didik di SMK Negeri 2 Karawang pada semester genap tahun ajaran 2020/2021. Populasi terjangkau dalam penelitian ini adalah seluruh peserta didik kelas $\mathrm{X}$ di SMK Negeri 2 Karawang pada semester genap tahun ajaran 2020/2021. Untuk menentukan populasi terjangkau pada penelitian ini dilakukan dengan teknik Cluster Random Sampling, yaitu teknik pengambilan anggota sampel yang memiliki karakteristik homogen atau relatif homogen dari populasi dilakukan secara acak dengan memperhatikan satrata yang ada dalam populasi (Lestari \& Yudhanegara, 2015). Sampel pada penelitian ini dipilih dari populasi terjangkau, pemilihan sampel dibatasi oleh jurusan dan guru yang sama. Setelah dilakukan uji prasyarat analisis data sebelum perlakuan sampel Pada tahap selanjutnya dipilih 2 dari 3 kelas menggunakan teknik simple random sampling, yaitu kelas $\mathrm{X}$ TB 1 sebagai kelas eksperimen dan kelas $\mathrm{X}$ TB 3 sebagai kelas kontrol.

Instrumen yang digunakan pada penelitian ini adalah tes kemampuan pemecahan masalah matematis. Yang sebelumnya telah diuji validitas isi, konstruk, dan empiris. Tabel 1 adalah interpretasi hasil uji validitas empiris instrumen penelitian yang menggunakan rumus koefisien Aiken's V. 
Tabel 1. Keterangan Validitas Empiris

\begin{tabular}{cccc}
\hline $\begin{array}{c}\text { No. } \\
\text { Soal }\end{array}$ & V & Keterangan & Kriteria \\
\hline 1 & 0,8883 & Valid & Sangat Tinggi \\
2 & 0,9117 & Valid & Sangat Tinggi \\
3 & 0,9351 & Valid & Sangat Tinggi \\
4 & 0,9429 & Valid & Sangat Tinggi \\
5 & 0,8416 & Valid & Sangat Tinggi \\
\hline
\end{tabular}

Berdasarkan hasil perhitungan reliabilitas dengan menggunakan teknik Alpha Cronbach diperoleh koefisien reliabilitas instrumen tes kemampuan pemecahan masalah matematika $(r)$ yaitu sebesar 0,7279 dan $\mathrm{r}_{\text {tabel }}$ sebesar 0,2826 maka $=0,7279>0,2826$. Hasil tersebut menunjukkan bahwa instrumen ini dinyatakan reliabel dan tingkat reliabilitas instrumen ini termasuk ke dalam kategori tinggi sehingga instrumen ini dapat dijadikan sebagai alat ukur penelitian.

\section{HASIL DAN PEMBAHASAN \\ Pengujian Persyaratan Analisis Sebelum Perlakuan}

Hasil dari pengujian normalitas sebelum perlakuan pada keempat kelas tersebut dapat dilihat pada Tabel 2.

Tabel 2. Perhitungan Uji Normalitas Sebelum Perlakuan

\begin{tabular}{lllll}
\hline Kelas & $L_{\text {hitung }}$ & $L_{\text {tabel }}$ & Keterangan & Kesimpulan \\
\hline X TB 1 & 0,132 & 0,148 & $L_{\text {hitung }}<L_{\text {tabel }}$ & Terima $H_{0}$ \\
X TB 2 & 0,193 & 0,150 & $L_{\text {hitung }}>L_{\text {tabel }}$ & Tolak $H_{0}$ \\
X TB 3 & 0,142 & 0,148 & $L_{\text {hitung }}<L_{\text {tabel }}$ & Terima $H_{0}$ \\
X TB 4 & 0,127 & 0,148 & $L_{\text {hitung }}<L_{\text {tabel }}$ & Terima $H_{0}$ \\
\hline
\end{tabular}

Berdasarkan hasil pengujian normalitas, dapat disimpulkan bahwa data nilai peserta didik sebelum perlakuan untuk kelas X TB 1, X TB 3, $\mathrm{X}$ TB 4 berdistribusi normal, sedangkan untuk kelas X TB 2 tidak berdistribusi normal.
Hasil dari perhitungan tersebut didapatkan

$$
\begin{aligned}
& X_{\text {Hitung }}^{2}=0,343, \\
& X_{(\alpha / 2) ;(k-1)}^{2}=7,378, \text { dan } \\
& X_{(1-\alpha / 2) ;(k-1)}^{2}=0,051 .
\end{aligned}
$$

Berdasarkan hasil tersebut, diperoleh bahwa $x_{\text {Hitung }}^{2}<X_{(\alpha / 2) ;(k-1)}^{2}$ yakni $0,343<7,378$ atau $x_{\text {Hitung }}^{2}>$ $X_{(1-\alpha / 2) ;(k-1)}^{2}$ yakni $0,343>0,051$. Artinya terima $H_{0}$ sehingga dapat disimpulkan bahwa tiga kelas yang diuji mempunyai ragam varians yang relatif seragam atau homogen pada taraf signifikansi $\alpha=0,05$.

Hasil dari pengujian kesamaan rata-rata pada kedua kelas tersebut dapat dilihat pada Uji ANAVA Tabel 3.

Tabel 3. Perhitungan Uji ANAVA Satu Arah

\begin{tabular}{cccccc}
\hline SV & $\mathrm{db}$ & $\mathrm{JK}$ & $\mathrm{KT}$ & $F_{\text {Hitung }}$ & $F_{\text {Tabel }}$ \\
\hline Perlakuan & 2 & 601,852 & 300,926 & 0,970 & 3,080 \\
Galat & 105 & 32572,222 & 310,212 & & \\
Total & 107 & 33174,074 & & & \\
\hline
\end{tabular}

Berdasarkan hasil perhitungan diperoleh $F_{\text {hitung }}<\mathrm{F}_{\text {tabel }}$ dengan $F_{\text {hitung }}=$ 0,970 dan $F_{\text {tabel }}=3,080$ maka terima $H_{0}$, atau tidak terdapat perbedaan rata-rata dari kelas X TB 1, X TB 3, dan X TB 4.

\section{Pengujian Persyaratan Analisis Setelah Perlakuan}

Hasil pengujian normalitas setelah perlakuan disajikan dalam Tabel 4.

Tabel 4. Perhitungan Uji Normalitas Setelah Perlakuan

\begin{tabular}{lcccc}
\hline \multicolumn{1}{c}{ Kelas } & $L_{\text {hitung }}$ & $L_{\text {tabel }}$ & Keterangan & Kesimpulan \\
\hline Kelas & 0,088 & 0,148 & $L_{\text {hitung }}<L_{\text {tabel }}$ & Terima $H_{0}$ \\
$\begin{array}{l}\text { Eksp. } \\
\text { Kelas } \\
\text { Kontrol }\end{array}$ & 0,116 & 0,148 & $L_{\text {hitung }}<L_{\text {tabel }}$ & Terima $H_{0}$ \\
\hline
\end{tabular}


Berdasarkan Tabel 4 dapat dilihat bahwa nilai $L_{\text {hitung }}$ kelas eksperimen lebih kecil dari pada nilai $L_{\text {tabel }}$ kelas eksperimen dan nilai $L_{\text {hitung }}$ kelas kontrol lebih kecil dari pada nilai $L_{\text {tabel }}$ kelas kelas kontrol maka dapat disimpulkan bahwa data nilai tes kemampuan pemecahan masalah matematis peserta didik kelas eksperimen maupun kelas kontrol sama-sama berdistribusi normal.

Hasil perhitungan uji homogenitas setelah perlakuan dapat dilihat pada Tabel 5.

Tabel 5. Hasil Uji Homogenitas Setelah Perlakuan

\begin{tabular}{ccc}
\hline $\boldsymbol{F}_{\text {Hitung }}$ & $\boldsymbol{F}_{\left(\mathbf{1}-\frac{\mathbf{1}}{2} \boldsymbol{\alpha}\right)\left(\boldsymbol{n}_{\mathbf{1}}-\mathbf{1}, \boldsymbol{n}_{\mathbf{2}}-\mathbf{1}\right)}$ & $\boldsymbol{F}_{\frac{\mathbf{1}}{\mathbf{2}} \boldsymbol{\alpha}\left(\boldsymbol{n}_{\mathbf{1}}-\mathbf{1}, \boldsymbol{n}_{\mathbf{2}}-\mathbf{1}\right)}$ \\
\hline 1,287 & 1,961 & 0,510 \\
\hline
\end{tabular}

\begin{tabular}{cc}
\hline Keterangan & Kesimpulan \\
\hline$F_{\text {Hitung }}<F_{\left(1-\frac{1}{2} \alpha\right)\left(n_{1}-1, n_{2}-1\right)}$ & Tolak $H_{0}$ \\
$F_{\text {Hitung }}>F_{\alpha\left(n_{1}-1, n_{2}-1\right),}$ & \\
\hline
\end{tabular}

Berdasarkan Tabel 5, diperoleh $F_{\text {Hitung }}>F_{\alpha\left(n_{1}-1, n_{2}-1\right)}$ atau $F_{\text {Hitung }}<$ $F_{\left(1-\frac{1}{2} \alpha\right)\left(n_{1}-1, n_{2}-1\right)}$ maka tolak Tolak $H_{0}$, artinya terdapat perbedaan varians antara kelas eksperimen dan kelas kontrol atau tidak homogen pada taraf signifikansi $\alpha=0,05$. Selanjutnya statistik uji yang digunakan adalah Uji-t dari dua kelompok sampel independen. Karena sampel tidak homogen, maka statistik yang digunakan adalah Uji-t'.

\section{Uji Analisis Data}

Pengujian hipotesis dilakukan dengan menggunakan statistik uji-t' dengan menggunakan taraf signifikansi $\alpha=0,05$, dengan kriteria pengujian tolak $H_{0}$ jika $t^{\prime} \geq \frac{w_{1} t_{1}+w_{2} t_{2}}{w_{1}+w_{2}}$.
Berdasarkan hasil pengujian, diperoleh nilai $t^{\prime}=3,190$ dengan nilai

$$
\frac{w_{1} t_{1}+w_{2} t_{2}}{w_{1}+w_{2}}=1,690 \text {. }
$$

Oleh karena itu

$$
t^{\prime}>\frac{w_{1} t_{1}+w_{2} t_{2}}{w_{1}+w_{2}}
$$

maka tolak $H_{0}$. Sehingga, dapat disimpulkan bahwa pada materi barisan dan deret yaitu rata-rata hasil tes kemampuan pemecahan masalah matematis kelas eksperimen lebih tinggi dari kelas kontrol.

\section{Uji Besar Pengaruh}

Tabel 6 merupakan hasil hitung dan interpretasi besar pengaruh signifikan yang telah didapatkan.

Tabel 6. Hasil Perhitungan dan Interpretasi Uji Cohen's d

\begin{tabular}{ccc}
\hline $\begin{array}{c}\text { Besar Pengaruh } \\
(d)\end{array}$ & $\begin{array}{c}\text { Presentase } \\
(\%)\end{array}$ & $\begin{array}{c}\text { Kategori } \\
\text { Cohen's }\end{array}$ \\
\hline 0,8 & $79 \%$ & Besar \\
\hline
\end{tabular}

Berdasarkan Tabel 6, nilai besar pengaruh yaitu 0,8 dengan presentase $79 \%$ dan masuk ke dalam kategori besar.

\section{PEMBAHASAN}

Penelitian dilakukan pada peserta didik SMK Negeri 2 Karawang kelas X semester genap tahun ajar 2020/2021, dengan menggunakan dua kelas yaitu kelas X TB 1 sebagai kelas eksperimen dan kelas X TB 3 sebagai kelas kontrol. Penelitian ini memiliki tujuan untuk mendapatkan informasi apakah model pembelajaran ICARE (Inroduction, Connect, Apply, Reflect, Extend) pada pembelajaran jarak jauh memberi pengaruh yang signifikan terhadap kemampuan pemecahan masalah 
matematis peserta didik di SMK Negeri 2 Karawang.

Kelas eksperimen mengggunakan langkah-langkah model pembelajaran ICARE pada pembelajaran jarak jauh. Pembelajaran di kelas ini dipusatkan pada peserta didik, pada setiap pertemuan, peserta didik mendapatkan kesempatan agar dapat mengungkapkan pengetahuan atau pemahaman mengenai pelajaran yang telah dijelaskan oleh guru dan melakukan diskusi secara berkelompok, dengan ini peserta didik secara langsung terlibat pada semua proses pembelajaran terutama pada saat proses pemecahan masalah. Hal ini selain dapat membuat peserta didik terlatih untuk mengatasi masalah juga menjadikan bisa bekerja sama dan terampil mengemukakan pemikiran di depan guru dan teman-temannya. Lalu, pada akhir pembelajaran di setiap pertemuan, peserta didik diberikan kesempatan untuk memperluas pengetahuan dengan berbagai sumber yang diberikan oleh guru.

\begin{tabular}{lrrr}
\multicolumn{2}{c}{ Pembelajaran } & ICARE & pada \\
pembelajaran & jarak & jauh & dapat \\
mendukung & peserta & didik & dalam
\end{tabular}
mengembangkan kemampuan pemecahan masalah melalui lima tahap. Langkahlangkah pembelajaran tersebut dapat melatih peserta didik untuk membangun sendiri pemikirannya mengenai materi yang diajarkan dan melatih untuk menyelesaikan masalah matematika yang diberikan. Pada tahap introduction (pengenalan), guru memastikan setiap peserta didik siap memulai pembelajaran untuk peserta didik dapat mengerti materi atau masalah matematika yang akan diberikan oleh guru. Kegiatan tersebut dilakukan melalui aplikasi Google Classroom, yang ditandai dengan mengisi daftar hadir. Pada tahap ini, guru juga memberikan motivasi, apersepsi, dan pengenalan materi yang akan digunakan pada pertemuan tersebut. Pengenalan materi dilakukan dengan mengirim video pembelajaran dan power point yang berkenaan dengan materi prasyarat. Untuk tahap selanjutnya peserta didik diarahkan untuk mulai bergabung pada video conference dengan menggunakan aplikasi Zoom Meeting yang telah disiapkan oleh guru.

Tahap Connect (menghubungkan) yang merupakan kelanjutan dari tahap sebelumnya dimana guru memaparkan tujuan dari pembelajaran dan penerapannya untuk kehidupan seharihari serta kaitannya dengan materi sebelumnya yang dilakukan melalui aplikasi Zoom Meeting. Hal ini mendukung peserta didik untuk dapat menghubungkan materi sebelumnya dengan materi yang baru diajarkan. Selanjutnya, guru memberi pertanyaanpertanyaan yang ada kaitannya dengan masalah yang diberikan, agar peserta didik terpacu untuk menemukan pemecahan dari masalah matematis tersebut, hal ini mendukung peserta didik untuk membentuk pengetahuannya mengenai pemecahan masalah secara mandiri, setara dengan hasil penelitian yang dilakukan oleh Putu dan kawankawan (2019). Di dalam tahap ini juga guru mulai memaparkan materi melalui PPT yang ditampilkan pada layar komputer.

Dalam pelaksanaanya ditemukan beberapa kendala saat pelaksanaan 
tahapan Connect, pada saat tahap Connect kendala yang dirasakan adalah terkadang beberapa peserta didik tidak dapat bergabung dalam zoom meeting akibat masalah jaringan, akibatnya ada beberapa peserta didik terpaksa tidak mengikuti video conference, solusi yang dilakukan oleh guru adalah dengan merekam jalannya video conference lalu dibagikan pada peserta didik agar seluruhnya mempunyai kesempatan setara untuk mempelajari materi pada pertemuan saat itu.

Selanjutnya yaitu tahap Application (penerapan), disini guru telah mengelompokkan peserta didik ke dalam 7 kelompok heterogen dengan berangggota 5-6 peserta didik, dan disusun berdasarkan nilai ujian sebelumnya. Guru memberikan tugas berupa LKPD melalui aplikasi Google Classroom dimana peserta didik dapat mengunduh LKPD. Latihan soal tersebut dilakukan per kelompok. Diskusi dilakukan secara online melalui forum diskusi pada aplikasi Google Classroom agar guru dapat mengawasi dan memastika setiap peserta didik berkontribusi dalam diskusi kelompok tersebut, peserta didik juga diberikan kesempatan untuk bertanya pada guru apabila ada kesulitan. Peserta didik mendapatkan kesempatan untuk mengaplikasikan pengetahuan yang sudah didapat pada tahap sebelumnya dengan diberikan latihan soal berupa soal pemecahan masalah yang disusun pada LKPD.

Selanjutnya, kendala yang dirasakan pada saat tahap Application yaitu saat diskusi kelompok, kendala yang dirasakan adalah keterbatasan waktu. Karena, tahap Aplication merupakan tahap yang paling banyak membutuhkan waktu, sesuai dengan pembahasan dalam penelitian yang dilakukan oleh Maskur dan kawankawan (2012). Hal ini ditangani oleh guru dengan tetap membahas jawaban dari LKPD tersebut. Lalu, karena beberapa peserta didik yang tidak dapat membuka aplikasi Google Classroom, maka dari itu, guru mengizinkan untuk membuat grup diskusi melalui aplikasi Whatsapp. Melalui Whatsapp group, guru tetap dapat mengawasi jalannya diskusi, hal ini berlaku juga pada kelas kontrol.

Setelah melakukan diskusi kelompok dan mendapatkan hasil dari diskusi tersebut pembelajaran dilanjutkan dengan tahap Reflection (refleksi), yaitu peserta didik diminta menjelaskan kembali hasil dari diskusi kelompok yang dilakukan pada tahap sebelumnya. Guru memberi kesempatan pada peserta didik agar merefleksikan pemahaman peserta didik tentang hal yang telah didapatkan dari pertemuan hari itu dengan cara memberikan pertanyaan kepada peserta didik mengenai apa saja yang sudah dipelajari lalu apa saja yang telah dipahami dan yang belum dipahami. Hal ini akan membuat guru dapat menilai seberapa jauh pemahaman peserta didik dan bisa dengan mudah mengerti materi yang telah dipelajari. Namun, terkadang tahap ini kurang berjalan dengan baik karena terkendala waktu. Oleh karena itu, guru memperbolehkan tahap ini dapat dilakukan melalui aplikasi Google Classroom maupun secara langsung melalui aplikasi Zoom Meeting. 
Tahapan yang terakhir adalah Extension (perluasan), pada tahap ini guru memberikan tugas berupa latihan soal atau tugas merangkum materi setiap pertemuan agar peserta didik selalu mencatat materi yang dipelajari, tugas tersebut dikerjakan secara individu. Lalu, guru memberikan sumber-sumber pembelajaran lain berupa link sumber pembelajaran yang dapat diakses oleh peserta didik, hal tersebut diberikan guna memperluas pengetahuan peserta didik. Model pembelajaran ICARE pada pembelajaran jarak jauh yang telah dipaparkan, seluruhnya telah dirancang agar dapat meningkatkan kemampuan pemecahan masalah matematis peserta didik.

Selanjutnya, proses belajar yang diterapkan di kelas kontrol yaitu pembelajaran konvensional. Pembelajaran konvensional pada penelitian ini merupakan pembelajaran jarak jauh yang sudah diterapkan sebelumnya oleh guru tanpa adanya arahan dari peneliti. Aplikasi penunjang dan LKPD yang digunakan pada kelas ini sama dengan yang digunakan pada kelas eksperimen, hal ini dilakukan agar hasil yang didapat adalah murni pengaruh dari model pembelajaran yang diberikan. Pembelajaran pada kelas kontrol samasama menggunakan aplikasi Google Classroom dan Zoom Meeting.

Tahap pertama yang dilakukan guru adalah mempersiapkan peserta didik. Peserta didik diarahkan mengisi daftar kehadiran pada aplikasi Google Classroom. Lalu, guru memberikan materi berupa link video pembelajaran dan power point. Langkah selanjutnya guru memulai video converence dengan menggunakan aplikasi Zoom Meeting. Video converence tidak selalu dilakukan setiap pertemuan, karena kurang adanya antusiasme peserta didik yang mengakibatkan hanya sedikit peserta didik yang dapat bergabung dan karena hal tersebut, video converence hanya dilakukan 3 kali dari total 7 kali pertemuan, sisanya guru menjelaskan materi hanya menggunakan forum diskusi melalui aplikasi Google Classroom.

Tahap kedua, guru memaparkan materi melalui power point lalu memberikan contoh soal mengenai materi tersebut. Setelah itu, guru memberikan latihan soal secara bertahap, dari soal yang paling sederhana sampai yang cukup rumit. Pada awal pemberian soal, pengerjaannya dilakukan bersama-sama, artinya disini guru ikut serta membantu peserta didik dalam menyelesaikan soal. Selanjutnya, guru memberikan latihan mandiri berupa LKPD dimana peserta didik menyelesaikan soal dengan cara mandiri. Tahap selanjutnya adalah mempresetasikan hasil pengerjaan soal, tetapi karena terkendala waktu dan peserta didik belum menyelesaikan soal yang diberikan, mengakibatkan tahap ini kurang berjalan dengan baik, lalu guru melanjutkan dengan memberikan tugas mandiri berupa soal yang akan dijelaskan pada pertemuan selanjutnya.

Pada proses pembelajaran konvensional guru menjadi pusat dari pembelajaran, di mana tahap pada pembelajarn ini kurang memberi peluang pada peserta didik agar dapat membentuk pengetahuannya sendiri yang mengakibatkan peserta didik sangat bergantung dengan contoh yang 
dijelaskan guru dan mendapatkan kesulitan apabila memperoleh soal berbeda atau lebih sulit, akibatnya pembelajaran menjadi kurang efektif dan kurang berkembangnya kemampuan peserta didik dalam memecahkan masalah matematika. Sedangkan dalam pembelajaran ICARE, guru menjadi fasilitator dan peserta didik dapat secara mandiri mengkontruksi pengetahuannya mengenai pemecahan masalah. Hal ini yang menjadi perbedaan dari kedua kelas sampel. lalu, faktor semangat peserta didik juga memengaruhi proses pembelajaran, dilihat dari antusias peserta didik dalam mengejakan LKPD yang diberikan guru dan tingkat kehadiran peserta didik.

Pengujian hipotesis statistik pada penelitian ini, memperlihatkan adanya perbedaan rata-rata tes kemampuan pemecahan masalah matematis peserta didik pada materi barisan dan deret antara kelas eksperimen yang belajar dengan model pembelajaran ICARE pada pembelajaran jarak jauh dan kelas kontrol yang belajar dengan pembelajaran konvensional. Perbedaan kedua kelas ditunjukkan dengan hasil rata-rata post test peserta didik kelas eksperimen lebih tinggi dibandingkan dengan kelas kontrol.

Berdasarkan hasil tersebut didapatkan rata-rata hasil post test peserta didik kelas eksperimen adalah 82,4 dan kelas kontrol adalah 71,9 maka, didapatkan disimpulkan bahwa model pembelajaran ICARE pada pembelajaran jarak jauh memberi pengaruh yang positif terhadap kemampuan pemecahan masalah matematis peserta didik dibandingkan dengan pembelajaran konvensional. Model pembelajaran ICARE pada pembelajaran jarak jauh yang diimplementasikan pada kelas eksperimen juga memberikan pengaruh sebesar 0,8 dengan presentase $79 \%$ dan termasuk dalam kategori large (besar). Besar pengaruh tersebut kurang maksimal karena adanya beberapa kendala pada saat proses pembelajaran seperti kendala waktu, jaringan, dan komunikasi jarak jauh yang kurang efektif dibandingkan dengan komunikasi secara tatap muka. Berdasarkan pemaparan di atas, model pembelajaran ICARE pada pembelajaran jarak jauh tidak memberikan pengaruh yang maksimal tapi termasuk kategori large (besar).

Hasil penelitian ini sejalan dengan penelitian yang dilakukan oleh Yasa et al., (2019) yang menunjukan bahwa kemampuan pemecahan masalah peserta didik yang diajarkan dengan model pembelajaran ICARE berbantuan masalah matematika terbuka lebih baik dibandingkan kemampaun pemecahan masalah peserta didik yang diajarkan dengan model konvensional. Lalu, penelitian yang dilakukan oleh Putu et al., (2019) menunjukkan bahwa perangkat pembelajaran berbasis model pembelajaran ICARE berbantuan GeoGebra efektif untuk meningkatkan kemampuan pemecahan masalah matematis peserta didik. Oleh karena itu, dapat disimpulkan bahwa, model pembelajaran ICARE pada pembelajaran jarak jauh memberikan pengaruh positif terhadap kemampuan pemecahan masalah matematis peserta didik pada materi barisan dan deret. 


\section{PENUTUP}

Dari hasil analisis data dan pembahasan yang bertumpu pada hiotesis yang telah dirumuskan dengan tingkat kepercayaan 95\%, maka dapat disimpulkan beberapa hal yaitu, Ratarata nilai post test kemampuan pemecahan masalah matematis peserta didik pada materi barisan dan deret kelas eskperimen ialah 82,4, sementara kelas kontrol ialah 71,9, di mana didapatkan nilai $t^{\prime}=3,190$ dengan nilai $\frac{w_{1} t_{1}+w_{2} t_{2}}{w_{1}+w_{2}}=1,690$ sehingga tolak $H_{0}$. Keputusan tersebut memiliki arti bahwa rata-rata hasil tes kemampuan pemecahan masalah matematis kelas eksperimen yang belajar menggunakan model pembelajaran ICARE (Inroduction, Connect, Apply, Reflect, Extend) pada pembelajaran jarak jauh lebih tinggi dari kelas kontrol yang belajar menggunakan model pembelajaran konvensional pada pembelajaran jarak jauh. Selain itu, diperoleh kesimpulan bahwa penerapan model pembelajaran ICARE pada pembelajaran jarak jauh berpengaruh secara signifikan terhadap kemampuan pemecahan masalah matematis peserta didik di SMK Negeri 2 Karawang tahun ajar 2020/2021 pada materi barisan dan deret. Selanjutnya, Besar pengauh penerapan model pembelajaran ICARE pada pembelajaran jarak jauh terhadap kemampuan pemecahan masalah matematis peserta didik di SMK Negeri 2 Karawang pada materi barisan dan deret sebesar 0,8 atau $79 \%$ yang termasuk ke dalam kategori large atau besar.
Beberapa hal yang direkomendasikan untuk peneliti selanjutnya adalah sebaiknya pembelajaran disiapkan dengan baik dan matang agar pembelajaran sesuai dengan alokasi waktu yang telah ditentukan, karena model pembelajaran ICARE pada penerapanya membutuhkan waktu yang sedikit lebih lama terutama pada tahap apply dan reflect. Peneliti juga dapat mengembangkan penelitian menggunakan model pembelajaran ICARE pada pembelajaran jarak jauh, dengan materi berbeda, dengan alokasi waktu yang lebih panjang, atau menggunakan aplikasi yang berbeda dan melakukan perbaikan berdasarkan penelitian yang sudah dilakukan terutama pada tahapan yang paling berpengaruh dalam model pembelajaran ini yaitu tahap apply dan reflect.

\section{DAFTAR PUSTAKA}

Carni, Maknun, J., \& Siahaan, P. (2016). Preface: International Conference on Recent Trends in Physics (ICRTP 2016). In Journal of Physics: Conference Series (Vol. 755 , Issue $1)$. https://doi.org/10.1088/17426596/755/1/011001

Hanifah, H., Supriadi, N., \& Widyastuti, R. (2019). Pengaruh Model Pembelajaran E-learning Berbantuan Media Pembelajaran Edmodo Terhadap Kemampuan Pemecahan Masalah Matematis Peserta Didik. NUMERICAL: Jurnal Matematika Dan Pendidikan Matematika, 3(1), 3142.

https://doi.org/10.25217/numerica 1.v3i1.453

Kemendikbud. (2019). Laporan Hasil 
Ujian Nasional. Pusat Penilaian Pendidikan.

https://hasilun.puspendik.kemdikb ud.go.id/\#2019!smp!capaian_nasi onal!99\&99\&999!T\&T\&T\&T\&1 $\& ! 1 ! \&$

Kusuma, J. W., \& Hamidah, H. (2020). Perbandingan Hasil Belajar Matematika Dengan Penggunaan Platform Whatsapp Group dan Webinar Zoom Dalam Pembelajaran Jarak Jauh Pada Masa Pandemik Covid 19. JIPMat, 5(1).

https://doi.org/10.26877/jipmat.v5 i1.5942

Lestari, K. E., \& Yudhanegara, M. R. (2015). Penelitian Pendidikan Matematika. PT Refika Aditama.

Maryam, S. (2016). "Pembelajaran Matematika dengan Strategi ICARE (Introduction, Connection, Application, Reflection, Extension) untuk Meningkatkan Kemampuan Pemecahan Masalah Matematis Siswa." In Universitas Islam Negeri Syarif Hidayatullah.

Maskur, A., Waluya, S. B., Dasar, P. P., Pascasarjana, P., \& Semarang, U. N. (2012). siswa meliputi mendengarkan keterangan. 1(2).

NCTM. (2000). Summary Principles and Standards for School Mathematics. NCTM Inc.

Nurani, N. I., Uswatun, D. A., \& Maula, L. H. (2020). Analisis Proses Pembelajaran Matematika Berbasis Daring Menggunakan Aplikasi Google Classroom Pada Masa Pandemi Covid-19. Jurnal PGSD, 6(1), 50-56.

OECD. (2019). What Students Know and Can Do: Indonesia. Oecd, 110. https://www.oecdilibrary.org/education/pisa-2018- results-volume-iii_bd69f805-

en\%0Ahttps://www.oecd-

ilibrary.org//sites/bd69f805-

en/index.html?itemId=/content/co

mponent/bd69f805-en\#fig86

Putu, N., Dewi, R., \& Ardana, I. M. (2019). Efektivitas Model ICARE Berbantuan Geogebra Untuk Meningkatkan Kemampuan Pemecahan Masalah Matematis Siswa. 3(1), 109-122.

Rosselyne, Ellis Salsabila, \& Dwi Antari Wijayanti. (2020). Pengaruh Model Pembelajaran Creative Problem Solving dengan Teknik Scaffolding Terhadap Kemampuan Pemecahan Masalah Matematis Siswa di SMA Negeri 12 Jakarta. Jurnal Riset Pembelajaran Matematika Sekolah, 4(1), 51-57. https://doi.org/10.21009/jrpms.04 1.08

Utami, R. W., \& Wutsqa, D. U. (2017). Analisis kemampuan pemecahan masalah matematika dan selfefficacy siswa SMP negeri di Kabupaten Ciamis. Jurnal Riset Pendidikan Matematika, 4(2), 166. https://doi.org/10.21831/jrpm.v4i2 .14897

Yumiati, Y., \& Wahyuningrum, E. (2015). Pembelajaran ICARE (Inroduction, Connect, Apply, Reflect, Extend) Dalam Tutorial Online Untuk Meningkatkan Kemampuan Pemecahan Masalah Matematis Mahasiswa UT. Infinity Journal, 4(2), 182. https://doi.org/10.22460/infinity.v $4 \mathrm{i} 2.81$ 